\title{
Pleistocene reef development in Bulukumba, South Sulawesi
}

\author{
Andi Muhammad Imran ${ }^{1}$, Ratna Husein ${ }^{1}$, Meutia Farida ${ }^{1}$, and Afdan Prayudi ${ }^{1}$ \\ ${ }^{1}$ Geological Department, Hasanuddin University, Kampus Unhas Tamalanrea, Makassar 90245, Indonesia
}

\begin{abstract}
Quaternary reefs are commonly studied right now to explain climate change during that time. They act as a good archive of climate change, because their development is influenced by climate condition. The research area is located in the southern tip of Bulukumba Regency, South Sulawesi. The objective of this research is to define the development of the reef. Methods applied in this research are field survey of 4 line transects along reef cliff. Laboratory work is mostly on petrographic and biofacies analyses in order to reconstruct the reef development. Four reef biofacies have developed in this study namely 1) Coralgal framestone - wackestone, 2) Massive coral framestone facies, 3) Platylike coral Bindstone facies, and 4) Branching Coral Bafflestone facies. Based on the facies association and organism accumulation, the reefs are interpreted to be developed within a reef complex in a shallow marine environment.
\end{abstract}

\section{Introduction}

Pleistocene coral reefs in eastern part of Indonesia are abundantly found along the coast. Coral reefs well developed in this area due to a wide shallow marine environment. The reefs exposed by an uplifting and form terraces. Kennedy and Woodroffe [1] reported that the tropical reefs develop in a complex variety of ways and commonly form fringing reefs. The principal factor that appears to determine the growth and morphology of fringing reefs is the available accommodation space controlled by sea level.

Coral reef is an important archive of climate change, because coral is a sensitive organism toward climate changes. Experts believe that some climate change events in the past such as El-Nino are well preserved within the coral skeleton as long as they do not experience a diagenesis. These proxy climate indicators provide paleoclimatic records which are important for the assessment of the global climate system and the mechanisms of decadal climate variability [2]. It is clear that the study on climate change in the past could help to predict the climate changes in the future.

Bira area consists of Plio-Pleistocene reef, Pleistocene reef and even modern reef. They are a member of the Selayar Limestone, Walanae Formation [3], [4]. The rocks are exposed in several terraces indicating sea level fluctuations and/or tectonic activities during their development. The study area experienced the rapture, forming terraces of limestone reefs [5] indicated by the presence of notches. The purpose of this study is to determine biofacies and depositional environment based on reef developments.

\section{Methods}

The study focus on Lower Terrace unit which has Pleistocene age. The study area locates at Bira and P. Liukang Loe, Bulukumba region (Fig. 1). Method applied in this study were field survey of 5 line transects, laboratory analysis and data processes. Facies data was taken along line transect with perpendicular and parallel to the shoreline. Laboratory work was done for petrography and paleontology analyses.

\section{Geological setting}

Pleistocene reef is a younger unit in the carbonate series of Selayar Limestone [5]. The rock is a member of the Walanae Formation formed within the Walanae Depression [3], \{4]. The Plio-Pleistocene event was accompanied by general uplift of the region and triggered most of Quaternary deposit to be exposed including Walanae Formation. The local appearance of thin coal layers at the upper part of the Walanae Formation may indicate the beginning of this uplift. It continued to the raised Pleistocene coral reefs in the southern of Walanae Depression. The reef unconformably overlies siliciclastic rock of Walanae Formation [6].

Stratigraphy of the area (Table 1) is composed by 1 ) lower Late Miocene foraminiferal limestones, 2) upper Late Miocene to Pliocene coral reef, 3) Pliocene coralgal reef and 4) Pleistocene coral reef [5]. Each unit is characterized by terrace showing oldest rock exposes landward with high altitude and youngest one seaward

\footnotetext{
* Correspondent author: mudhimran@gmail.com
} 
with lower altitude. Lower terrace has been described as a lower Pleistocene reef [5] and in Selayar Island was dated as very early Pleistocene or 1.6 to $1.4 \mathrm{Ma}$ [7].

Selayar Limestone, which crops out in the Bulukumba region shows a reef complex dominated by coral reef. Based on fossil contents such as coral, larger foraminiferal assemblage and lithologic characteristics, the Selayar Limestone is informally divided into four reef biofacies have developed in this study namely 1 ) Coral gal framestone - wackestone, 2) Massive coral framestone facies, 3) Platy-like coral Bindstone facies, 4) Branching Coral Bafflestone facies. Based on the facies association and organism accumulation, the reefs are interpreted to be developed within a reef complex in a shallow marine environment.
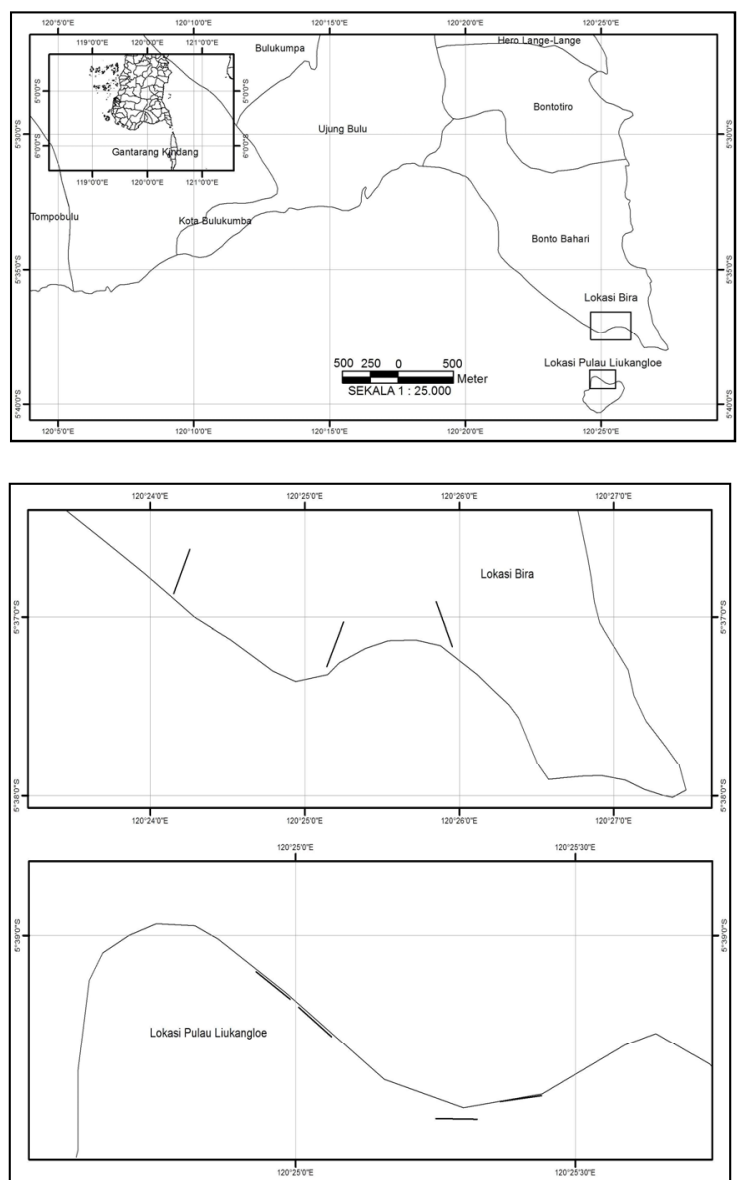

Fig. 1. Location map of the study area of Bira and Liukang Loe area

\section{Pleistocene reef}

Pleistocene reef is a raised coral reef [8] cropping out at the lower terraces of the Selayar Limestone [5]. The rock exposes in the southern tip of Bulukumba region and in the east cost of the Selayar Island. This study issubjected to the reef in the Bulukumba region. TheThe Pleistocene reef in Bulukumba composes four reef biofacies namely 1) Coralgal framestone wackestone facies, 2) Massive coral Framestone facies, 3) Platy-like coral Bindstone facies, 4)
Branching Coral Bafflestone facies. Based on the facies association and organism accumulation, the reefs are interpreted to be developed within a reef complex in a shallow marine environment.

Pleistocene reef unconformably overlies volcanic rock of the Walanae Formation [4] in Bira area. On the other hand the Walanae Volcanic does not expose in Pulau Liukangloe (small island closed to Bira).

Table 1. Stratigraphy of South Sulawesi and Selayar Limestone, modified from several authors [9, $3 \& 10]$.

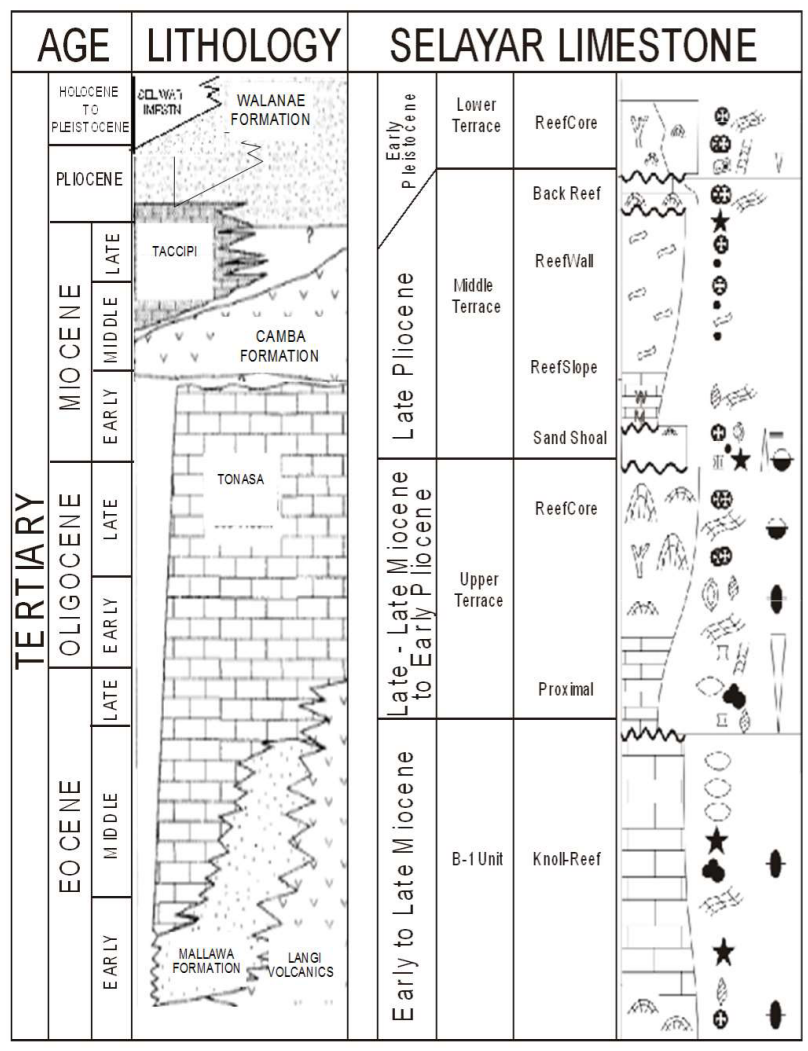

\subsection{Coralgal framestone - wackestone facies}

The coralgal framestone-wackestone facies crops out just above present sea level as high as $80-160 \mathrm{~cm}$ at P. Liukangloe and about $2-3 \mathrm{~m}$ at Bira area. It composes mainly of massive coral (Fig. 2a) and mud supported matrix. In a certain place, Tridacna sp. is present ingrowth position with up to $119 \mathrm{~cm}$ in diameter (Fig. 2B). The facies also consists of a rhodholithic lens with globular and encrusting habit at the Bira area. This encrusting algae has 1-30 $\mathrm{mm}$ in diameter. The lens forms graded bedding structure with rudstone texture. Fragments of red algae (Fig. 2C) and lithoclasts are common present in this facies. They are interpreted to be transported from upper part of the reef and accumulated in the fore reef [11]. Wackestone texture in which the grains commonly originated from coral indicates a low energy environment. Based on the bio-physical data, the facies is interpreted to develop in front reef in the open marine environment. (for 
example in accordance with the guidelines in the use of the font size)

\subsection{Massive coral framestone facies}

The facies consists of massive coral bed overlaying rhodholithic rudstone lens. The corals are predominantly of family Faviidae and Poritidae which have $1,5 \mathrm{~m}$ high and 10-45 cm diameter (Fig. 3A). To the west the coral gradually turns into a branching coral of the family Acroporidae. Tridacna sp. is commonly found at the basement of the facies (Fig. 3B) associating with small pelecypods and gastropods.

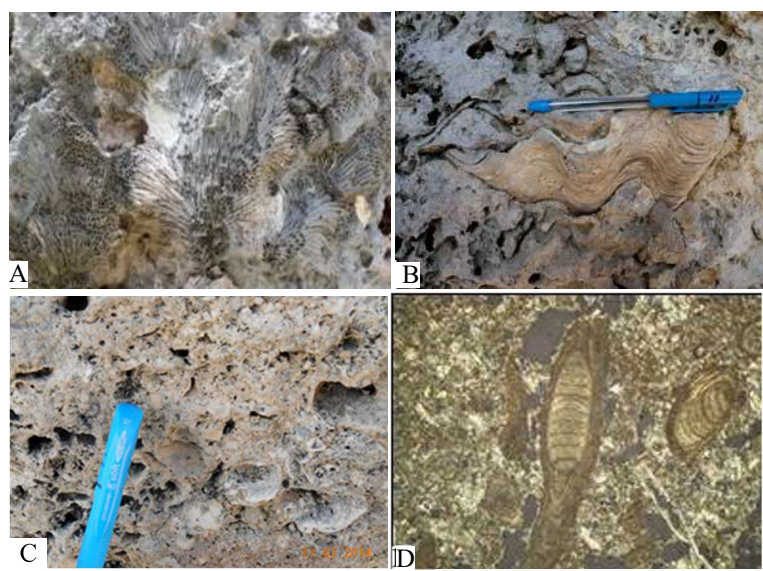

Fig. 2. Shows massive coral (A) and Tridacna sp. (B), rhodolit(C) and thin section of matrix showing red algae fragments (D) as components of massive coralgal framestone - wackestone facies.

Massive corals as a dominant organisms in growth position indicate a high energy environment with sufficient temperature and light [12]. The presence of Tridacna sp. with reference of modern sea of Spermonde Island, indicates a water depth $<10 \mathrm{~m}$ with good water circulation environment [5]. The condition mention above represents a reef front zone to reef flat [11], [12]. By the same characteristics, the facies is interpreted to be developed in reef core toward fore reef environment with a good circulation and sufficient sun light.
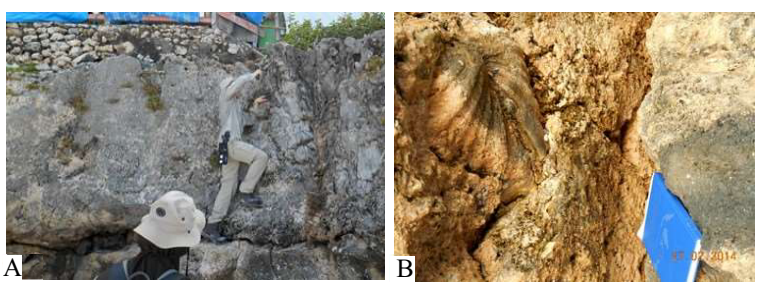

Fig. 3. Outcrop of massive coral framestone showing massive coral in growth position (A) and Tridacna sp exposed on the lower part of the facies (B).

\subsection{Platy-like coral Bindstone facies}

The facies is dominated by platy coral and coralline algae. The facies exposes at the western part of Bira beach and at the west side from Massive coral framestone facies.
The corals are predominantly of Acropora and genus Montipora in growth position. The coral dimension shows a different in size, where in P Liukangloe is larger than that in Bira area coral has (5 $-80 \mathrm{~cm}$ in length) (Fig. 4). Matrix of the facies is locally found and consist predominantly of grain from coral and red algae (Fig. 4C). The organism association indicates the depositional environment of the facies is a protected reef in lagoon.
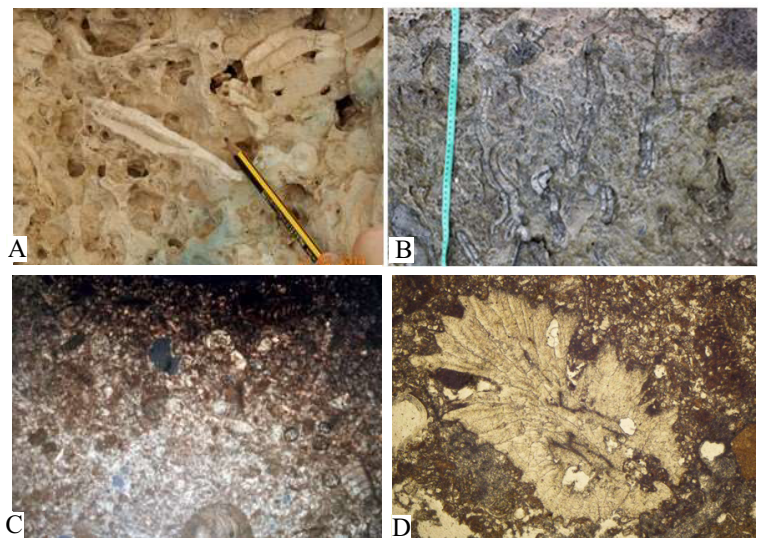

Fig. 4. Flatty coral in growth position at Bira area (A) and $P$ Liukang Loe (B) and thin section of matrix (C) and coral fragment (D).

\subsection{Branching coral bafflestone facies}

The facies has been highly abraded and partly refined by travertine deposits. The facies locates at cliff as high as 7 meter to the northern part and slightly flat at $\mathrm{P}$ Liukangloe. It consists commonly of delicate branching coral from Acropora robusta with $1-3 \mathrm{~cm}$ in diameter (Fig. $5 \mathrm{~A} \& \mathrm{~B}$ ). The texture of the matrix (Fig. 5C) shows skeletal grain support consisted of foraminifera, algae, echinoderms and gastropods. The association of the organism indicates a slightly high energy in reef front at 20-60 $\mathrm{m}$ depth [11], [13]. The organism and textural association suggests a shallow reef environment and is exposed to strong wave action.

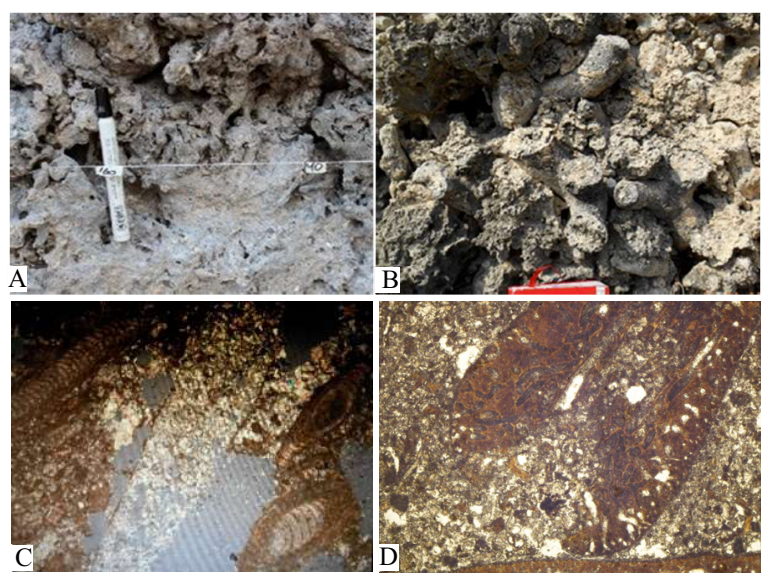

Fig. 5. Field view of robust branching coral at $P$ Liukangloe (A) and Bira (B). Thin section photograph of matrix showing red algae (C) and Halimeda fragments (D). 


\section{Fringing Reef Of Bira Area}

Fringing reef growth attaches to a landmass and form without or very narrow lagoon. It has variation in morphology and size. The reef produces a range of reef structures controlled by sea-level regional storm Climate [1]. It is possible to describe the variation between fringing reefs based on the nature of the antecedent surface that they are established over as well as the proportion of framework and detrital sediments within the reef structure [14].

The characteristics of the Pleistocene reef which is attached to the basement of shoreline, allow the reef to grow vertically and form reef flat during the still stand of sea level. This type of reef corresponds to the simple type of narrow fringing reef, proposed by Kennedy \& Woodroffe [1]. The reef growth responds to the sea level change by catching-up in shallow water environment (Fig. 6). This type of reef corresponds to the reef model A of Kennedy \& Woodroffe [1]. The reef consist of reef front, core reef and back reef with small lagoon. It is widespread surround the older reef where its lagoon is narrow in the north and reef front in the south.

\section{Conclusion}

The reef model proposed in this study is based on geomorphology and facies association of the reef. This model shows that both areas (Bira and P Liukangloe) form a narrow fringing reef. The Bira area developed from reef front to back reef. The reef was growing vertically by catching-up sea level and finally formed reef crest. The reef facies are constrained by pseudo bedding plane and they are interpreted to develop in different period. The first period was the establishment platy-like coral bindstone, coralgal framestone wackestone, and massive coral framestone facies. The second period was Branching coral bafflestone facies.
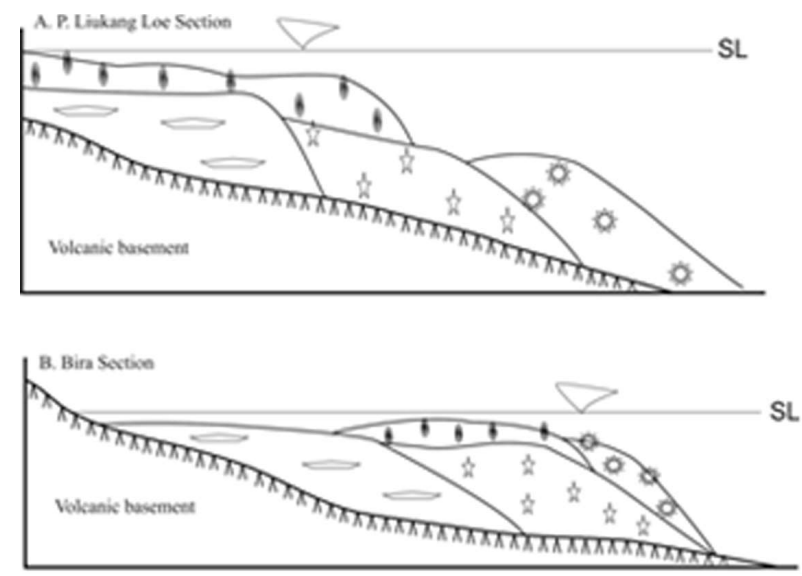

- 0 Masive coral boundtoone faxics

fo to Ceralgal framestonemadectuon faxie

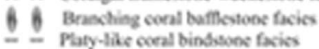

Fig. 6. Idealized of fasies development at the Bira Reef Complex (not to scale).
The author would like to thank to DIKTI for the financial support by research grant year $2015-2016$.

\section{References}

1. D.M. Kennedy and C.D, Elsevier, vol. 57. 255277. (2002)

2. T. Felis and J. Pätzold, Eds., M. Shiyomi et al., TERRAPUB (2004) pp. 205-227., (2004).

3. R. Sukamto and S. Supriatna, Geological Research Center General Directorate of Energy and Mining Department. (1982).

4. A. M. Imran, M. Farida, M. F. Arifin, R. Husain and A. Hafidz, Indonesian Journal on Geoscience 3 No. 1 53-66. (2016)

5. A. M. Imran. Microfacies and Diagenesis of the Tertiary Selayar Limestone (Walanae Formation), South Sulawesi, Indonesia. Dissertation, (2000). Universitat ErlangenNuermberg, Jerman. (unpublished)

6. T. M. van Leeuwen. The Geology and Tectonics of Eastern Indonesia, Geological Research and Development Center, Spec. Publ. No.2, (1981). 277-304.

7. K. Bromfield, Bulletins of American Paleontology, no 387 Des. (2013). 1-60.

8. R.W. Van Bemmelen. The geology of Indonesia: General Geology. (Government Printing Office, The Hague) Batavia,Indonesia. (1949). 40-441.

9. R. Sukamto, J. Geologi dan Sumberdaya Mineral. Bandung (Pusat Penelitian dan PengembanganGeologi). (1975) 2/1, 3-8.

10. A. M. Imran and R. Koch. In: 35th PIT IAGI Riau. Riau: IAGI. Code S-28. (2006). 8pp.

11. N.P. James. Reef Environment. in Schole, P. A., D. G. Bebout, \& C. H. Moore (Eds.), Carbonate Depositional Environments. Oklahoma: AAPG Memoir 33. (1983).

12. J. Veron. New Species Described In Corals of the World. Melbourne: Australian Institute of Marine Science Monograph Series, 11. 207 pp. (2002)

13. J.M. Webster, L Wallace, E. Silver, D. Potts, J.C. Braga, W. Renema, K. Riker-Coleman, C. Gallup. Marine Geology 204 (1-2), 59- 89. (2004)

14. D. Hopley, B. Partain. In: Baldwin, C.L. (Ed.), Fringing. Reef Workshop: Science, Industry and Management. Great Barrier Reef Marine Park Authority, Townsville, pp. 13-33. (1986) 